\title{
University College, Nairobi: Institute for Development Studies
}

THE Institute for Development Studies (IDS) was established on 8 October I965 at University College, Nairobi, replacing the Centre for Economic Research. It is a separate department within the Faculty of Arts, governed by an Executive Committee, under the chairmanship of Dr. A. T. Porter, Principal. The Institute has a Cultural Division and a Social Science Division; the latter is publishing a series of quarterly bulletins reporting on its research programme and activities. The programme will concentrate on the economic and social problems of developing countries, with particular attention to East Africa. Although some basic research will be included, the emphasis will be on policy-oriented research and it is expected that the Social Science Division will co-operate closely with the Kenya Government by conducting research on problems of economic and social development in Kenya.

Projects now in progress include studies of African industrial development and business enterprise, problems of agricultural development and marketing, land consolidation, parliament and provincial administration in Independent Kenya, and statistical studies. Current research activities of the Department of Geography include movements of population in Kenya, distribution of population in Kenya, and population and natural resources. The Social Science Division plans to continue the discussion paper series initiated by the Centre for Economic Research and several new papers have been published.

Further information on the activities of the Social Science Division of the Institute for Development Studies and particulars of its publications may be obtained from: The Secretary, Institute for Development Studies, University College, Nairobi, P.O. Box 30197, Nairobi, Kenya.

\section{University of Zambia: Institute for Social Research}

THE Rhodes-Livingstone Institute has now become the Institute for Social Research, the first unit of the Centre for African Studies in the University of Zambia. Its Director is Professor Alastair Heron. The journal of the Institute will be entitled African Social Research and will continue to appear twice a year. The R.L.I. papers will henceforth be known as Zambian Papers and will appear at irregular intervals but averaging one issue instead of two annually as previously. To provide for the possibility of similar papers from the School of Natural Sciences of the University, the Zambian Papers will be divided into two series, Social Sciences and Natural Sciences. The Institute will continue its Communications which will provide an economical and speedy outlet for preliminary reports by research workers. A Bulletin will also be produced at least once a year in place of Conference Proceedings. The Institute will be sending out a brochure early in 1966 describing its new role and the wider programme of research on which it is now engaged.

\section{U.S. Department of State: Research in Africa}

THE Office of External Research, U.S. Department of State, publishes External Research: Africa, a list of current social science research by private scholars and academic centres (ref. 5.24-1965). It records social science research on Africa currently in progress or completed during the period October 1964 to July 1965 and unpublished at the latter date. It is one of a series of lists based on the catalogue of social science research on foreign areas and international affairs compiled by the Office of External Research from information submitted by scholars and research centres throughout the United States. Copies of these 